\title{
Screening of Amazonian bacillus strains for lipase production using glycerol as substrate
}

\author{
Giandra Volpato
} Instituto Federal de Educação, Ciência e Tecnologia do Rio Grande do Sul (IFRS) Campus Porto Alegre (giandra.volpato@poa.ifrs.edu.br)

Victória Furtado Migliavacca Universidade Estadual do Rio Grande do Sul (UERGS) (victoria-migliavacca@uergs.edu.br)

Bruna Coelho de Andrade Pontifícia Universidade Católica do Rio Grande do Sul (PUCRS) (bruna.andrade.001@acad.pucrs.br)

Júlio Xandro Heck Instituto Federal de Educação, Ciência e Tecnologia do Rio Grande do Sul (IFRS) Campus Porto Alegre (julio@poa.ifrs.edu.br)

Marco Antônio Záchia Ayub Universidade Federal do Rio Grande do Sul (UFRGS) (mazayub@ufrgs.br)

\begin{abstract}
The industrial application of lipolytic enzymes has been studied mainly due to the ability of these enzymes in catalyze reactions of synthesis and their stability in various organic solvents. One possibility is the use of lipase the organic synthesis, taking advantage as the generation of waste and difficult recovery of sub bioproducts. In this work, we carried out a selection of eighty-four isolates of Bacillus amazonian for lipase production, of which 30 strains showed lipolytic activity. The study of the culture conditions was performed through a Plackett-Burman experimental design using the strain that presented the highest lipolytic activity in a culture medium using glycerol as substrate. The studied conditions were: concentration of soybean oil, olive oil, triton X-100, gum arabic, glycerol, and $\left(\mathrm{NH}_{4}\right)_{2} \mathrm{SO}_{4}, \mathrm{pH}$, temperature and concentration of inoculums. The best result obtained were $27 \mathrm{U} / \mathrm{L}$ in $48 \mathrm{~h}$ of cultivation by Bacillus circulans BL53. This work shows that the search and selection of microorganism with lipolytic activities can facilitate the discovery of new lipases, with potential use as by-product surplus.
\end{abstract}

Keywords: Screening; Glycerol; Lipase. 


\section{INTRODUCTION}

Lipases belong to the enzyme class of hydrolases (E.C.3) and they are an important group of biocatalysts with a swiftly growing biotechnology that is based mainly on their remarkable ability to carry out novel reactions in aqueous and nonaqueous media (SINGH \& MUKHOPADHYAY, 2012). Thus with the advent of rapid methods for discovering novel enzymes or altering the properties of enzymes, there is paramount interest in the development of screening tools that can be used to search for the best performance with respect to specific property. As each industrial application may require specific properties of the biocatalysts, there are still an interest in finding new lipases that could create novel applications (BASSEGODA et al., 2013). Therefore, the screening of microorganisms with lipolytic activities is essential research aiming to the discovery of novel lipases.

Numerous carbon sources, such as Tween 80, triolein, yeast extract, olive oil, soybean oil, silk oil, sesame oil, coconut oil, and corn oil, have been used as substrates to produce lipases in cultures of bacteria (LI et al., 2005; BURKERT et al., 2004). However, few investigations have been carried out using glycerol as substrate (LIN et al., 2006; VOLPATO et al., 2008; RECH et al., 2012). Glycerol can be utilized as a carbon source in microbial bioconversions for the production of a range of chemicals that might be utilized either as end-products or as precursors for the production of other chemicals, since this biofuel will be produced on a large scale in the coming years, large amounts of glycerol will be discarded and can be used in bioprocesses.

The determination of culture conditions for overproduction of the enzyme is an important step for its commercial usage and involves a number of physico-chemical parameters such as the composition of production medium, the carbon and nitrogen sources, pH and temperature (GUPTA et al., 2004). The use of statistical approach involving Plackett-Burman (PB) statistical designing have been widely used for media screening and for the understanding of interactions among various parameters using a minimum number of experiments (RAJENDRAN et al., 2008; ABU et al., 2017). Recent studies have shown the use of statistical approaches to culture conditions optimization to lipases production by different microorganisms such as 
Pichia guilliermondii (ABU et al., 2017), Bacillus cereus (VASIEE et al., 2016), and Yarrowia lipolytica (IMANDI et al., 2014).

This work deals of screening of Amazon Bacillus strains to produce lipase using glycerol as substrate and to study the effects of culture conditions on lipase production using Plackett-Burman statistical designing.

\section{MATERIAL AND METHODS}

\section{Screening of Amazon isolates}

The eighty-four bacterial used in this study were isolated from samples of soil and water of the Amazon region and stocks of these bacteria are kept at Microbiology Culture Collection of BiotecLab (UFRGS, Brazil). Strains were maintained on LB agar medium containing $1 \%$ of peptone, $0.5 \%$ of yeast extract, and $1 \%$ of $\mathrm{NaCl}$. Two assay methods were used to screen the lipolytic activity: a solid system (agar plates), for bacteria preselecting, and a liquid system (microplates).

The solid system was based on the spread plate technique content tributyrin agar. Cultures were grown at $37^{\circ} \mathrm{C}$ for $72 \mathrm{~h}$ and positive colonies were identified by the presence of a translucent halo around the colonies; commercial lipase was used as a positive control, and water as negative control (SOUZA et al., 2003).

In the liquid system, sterilized medium (LB supplemented with $10 \%$ of olive oil and $1 \%$ of gum arabic) was then homogenized in a blender, test tubes were inoculated with a single colony from an agar plate culture and incubated for $48 \mathrm{~h}$ at $37^{\circ} \mathrm{C}$ under agitation (180 rpm), the tube cultures were centrifuged at $15,000 \mathrm{~g}$ and 4 ${ }^{\circ} \mathrm{C}$ for $10 \mathrm{~min}$, and an aliquot of supernatant was removed to check extracellular activity, using SpectraMax Microplate Reader, with 96-well polystyrene microplates, according to methodology proposed by Winkler and Stuckmam (1979), with modifications.

\section{Media composition}

Through the tests described above were selected the strains with higher lipolytic activity. We tested six different media of cultivation, varying the source of carbon (glucose and glycerol), nitrogen source (organic and inorganic) and source of minerals (raw yeast extract and medium Bushnell-Haas), showed Table 1. Inoculum for all experiments were prepared in $250 \mathrm{~mL}$ Erlenmeyer flasks containing $40 \mathrm{~mL}$ of 
the culture medium. Flasks were inoculated with $5 \%$ of pre inoculum (medium LB, 18 $\mathrm{h}$ of culture, and agitation of $250 \mathrm{rpm}$ ), the initial $\mathrm{pH}$ was adjusted to 7.0 , incubated for $48 \mathrm{~h}$ at $37^{\circ} \mathrm{C}$, and $250 \mathrm{rpm}$. Samples were taken along the $48 \mathrm{~h}$ of cultivation to determine lipolytic activity, $\mathrm{pH}$ and optical density.

Table 1 - Culture media composition.

\begin{tabular}{ccccccc}
\hline & \multicolumn{2}{c}{ Carbon source $(\mathrm{g} / \mathrm{L})$} & \multicolumn{2}{c}{$\begin{array}{c}\text { Nitrogen source } \\
(\mathrm{g} / \mathrm{L})\end{array}$} \\
\cline { 3 - 7 } $\begin{array}{c}\text { Culture } \\
\text { Medium }\end{array}$ & Glycerol & Glucose & Peptone & $\left(\mathrm{NH}_{4}\right)_{2} \mathrm{SO}_{4}$ & $\begin{array}{c}\text { Raw } \\
\text { yeast } \\
\text { extract }\end{array}$ & Bushnell-Haas \\
\cline { 2 - 7 } & 10 & 0 & 10 & 0 & 5 & 0 \\
2 & 0 & 10 & 10 & 0 & 5 & 0 \\
3 & 10 & 0 & 0 & 10 & 5 & 0 \\
4 & 0 & 10 & 0 & 10 & 5 & 0 \\
5 & 10 & 0 & 0 & 10 & 0 & 5 \\
6 & 0 & 10 & 0 & 10 & 0 & 5 \\
\hline
\end{tabular}

\section{Plackett-Burman statistical design}

To determine which nutrients and conditions had a significant effect on lipase production, P-B design was used (PLACKETT \& BURMAN, 1947), with the strain that presented the highest lipolytic activity in previous experiments. In this paper, nine variables (concentration of soybean oil and olive oil; concentration of Triton X-100; concentration of gum arabic; concentration of glycerol; concentration of $\left(\mathrm{NH}_{4}\right)_{2} \mathrm{SO}_{4}$; initial $\mathrm{pH}$; temperature, and inoculum optical density) and two dummies variables were screened in 12 trials, in duplicate. The minimum and maximum ranges selected for the nine parameters are given in Table 2, in which each column represents an independent variable. Variables with confidence levels $>95 \%$ were considered to have significant influence on lipase production. 
Table 2 - Plackett-Burman experimental design matrix with lipolytic activity in $48 \mathrm{~h}$ of cultivation by Bacillus circulans BL53.

\begin{tabular}{ccccccccccc}
\hline $\begin{array}{c}\text { Trial } \\
\text { no. }\end{array}$ & & & \multicolumn{9}{c}{ Variables $^{\text {a/levels }}{ }^{\mathrm{b}}$} & & & \multicolumn{3}{c}{$\begin{array}{c}\text { Lipolityc Activity } \\
(\mathrm{U} / \mathrm{L})\end{array}$} \\
& $\mathrm{X}_{1}$ & $\mathrm{X}_{2}$ & $\mathrm{X}_{3}$ & $\mathrm{X}_{4}$ & $\mathrm{X}_{5}$ & $\mathrm{X}_{6}$ & $\mathrm{X}_{7}$ & $\mathrm{X}_{8}$ & $\mathrm{X}_{9}$ & \\
\hline 1 & + & - & + & - & - & - & + & + & + & 7.05 \\
2 & + & + & - & + & - & - & - & + & + & 1.46 \\
3 & - & + & + & - & + & - & - & - & + & 4.15 \\
4 & + & - & + & + & - & + & - & - & - & 4.41 \\
5 & + & + & - & + & + & - & + & - & - & 4.23 \\
6 & + & + & + & - & + & + & - & + & - & 8.64 \\
7 & - & + & + & + & - & + & + & - & + & 0.48 \\
8 & - & - & + & + & + & - & + & + & - & 1.89 \\
9 & - & - & - & + & + & + & - & + & + & 26.73 \\
10 & + & - & - & - & + & + & + & - & + & 11.41 \\
11 & - & + & - & - & - & + & + & + & - & 19.32 \\
12 & - & - & - & - & - & - & - & - & - & 16.30 \\
Effects & $-4.4^{*}$ & $-4.9^{*}$ & $-8.2^{*}$ & $-4.7^{*}$ & $1.2^{*}$ & $5.1^{*}$ & $-3.1^{*}$ & $3.1^{*}$ & 0.5 &
\end{tabular}

${ }^{\mathrm{a}} \mathrm{X}_{1}$ soybean oil: $(-)=5 \mathrm{~g} / \mathrm{L}, .(+)=20 \mathrm{~g} / \mathrm{L} ; \mathrm{X}_{2}$ olive oil: $(-)=5 \mathrm{~g} / \mathrm{L}, .(+)=20 \mathrm{~g} / \mathrm{L} ; \mathrm{X}_{3}$ Triton $\mathrm{X}-$ 100: $(-)=0 \mathrm{~g} / \mathrm{L}, .(+)=5 \mathrm{~g} / \mathrm{L} ; X_{4}$ gum arabic: $(-)=0 \mathrm{~g} / \mathrm{L}, .(+)=10 \mathrm{~g} / \mathrm{L} ; X_{5}$ glycerol: $(-)=10$ $\mathrm{g} / \mathrm{L}, . .(+)=30 \mathrm{~g} / \mathrm{L} ; \mathrm{X}_{6}\left(\mathrm{NH}_{4}\right)_{2} \mathrm{SO}_{4}:(-)=0 \mathrm{~g} / \mathrm{L}, .\left(^{+}\right)=5 \mathrm{~g} / \mathrm{L} ; \mathrm{X}_{7}$ initial pH: $(-)=5, .\left(^{+}\right)=8 ; \mathrm{X}_{8}$ temperature: $(-)=25^{\circ} \mathrm{C}, .(+)=37^{\circ} \mathrm{C} ; \mathrm{X}_{9}$ inoculum optical density $(-)=5 \%(\mathrm{v} / \mathrm{v}) . .(+)=10 \%$ $(v / v) .{ }^{b}(-)$ lower level,. $(+)$ higher level. ${ }^{*} p$-values $<0.05$.

\section{Analytical methods}

The cell-free supernatant of the culture broth, referred to as the crude extract, was used for the estimation of enzymatic activities and for $\mathrm{pH}$ determinations using a standard lab pHmeter.

Lipolytic activity was determined using a colorimetric method described for Winkler and Stuckmam (1979), using p-nitro-phenyl palmitate (pNPP) as the substrate. A volume of $0.15 \mathrm{~mL}$ crude enzyme extract was mixed with $1.35 \mathrm{~mL}$ of the prepared substrate solution and incubated at $37^{\circ} \mathrm{C}$ for $15 \mathrm{~min}$ in a water bath. Control containing heat-inactivated enzyme was also incubated with each assay. The reaction was measured as absorbance at $410 \mathrm{~nm}$. One unit of enzyme was defined as the amount of enzyme that liberated $1 \mu \mathrm{mol} p$-nitrophenol $\mathrm{min}^{-1}$ at $37^{\circ} \mathrm{C}$. 


\section{RESULTS AND DISCUSSION}

Thirty strains from the eighty-four studied, were selected respect with their lipolytic activities. Table 3 shows the results to of halos formed in agar tributyrin by strains pre-selected in this test, and lipolytic activity of these isolates. It was verified that the major lipolytic activities were obtained by the strains that presented the largest halos. The similar behavior was found by Bhatnagar et al. (2005) in the selection of lipase-producing halobacteria, these data indicate that although this method is qualitative, it can be considered very reliable. These authors have maximum lipolytic activity of $10.8 \mathrm{U} / \mathrm{L}$, using $\rho$-NPP as a substrate. Among the preselected strains in this work, the isolated BL13 presented the higher lipolytic activity (22.5 U/L).

We performed the statistical analysis of the results, through ANOVA and Tukey test, to verify the differences between the lipolytic activities obtained for each isolated. When the activities were considered statically equal, with confidence level of $95 \%$, they were grouped and identified by a superscript letter. The strains that showed higher lipolytic activity (groups A and B) were selected for the study of culture media composition. Thus, eight strains were selected, BL13, BL49, BL53, BL58, BL60, BL61, BL64 and BL74, as is evident in Table 3.

After select microorganisms with lipolytic activity, different source of carbon (glucose and glycerol), nitrogen (peptone and $\left(\mathrm{NH}_{4}\right)_{2} \mathrm{SO}_{4}$ ), and mineral (BushnellHaas and yeast extract) were tested for the lipase production of such strains. Table 4 presents the results of lipolytic activity for the previously selected strains, in the different cultures using glycerol (media 1, 3 and 5) or glucose (media 2, 4 and 6).

The higher lipolytic activity (26.9 U/L) was obtained by isolated BL53, previously identified as Bacillus circulans, in the culture medium containing glycerol as substrate (medium 1), suggesting that glycerol is a better source for microorganism growth and lipase production than glucose, for the studied strains. Volpato et al. (2008) and Lin et al. (2006), working with Staphylococcus caseolyticus and Antrodia cinnamomea, respectively, also described the induction of this enzyme by glycerol. Moreover, the lipolytic activities were higher in the media 1 and 2 , indicating that the use of peptone as a nitrogen source and raw yeast extract, a cheap substrate, are more interesting for lipase production by these strains, than the use of $\left(\mathrm{NH}_{4}\right)_{2} \mathrm{SO}_{4}$ and mineral medium Bushnell-Haas, respectively. From these 
results, we selected the isolated BL53 because it presented higher lipolytic activity in cultures containing glycerol as carbon source.

Table 3 - Amazonian isolates that showed lipolytic activity.

Strain Tributyrin Agar Plates Lipolytic Activity (U/L)

\begin{tabular}{|c|c|c|}
\hline BL7 & + & $7.4 \pm 0.2^{F G}$ \\
\hline BL9 & + & $9.9 \pm 0.2^{\mathrm{DEF}}$ \\
\hline BL10 & + & $10.3 \pm 0.0^{\mathrm{DEF}}$ \\
\hline BL12 & + & $10.3 \pm 0.4^{\mathrm{DEF}}$ \\
\hline BL13 & ++ & $22.5 \pm 0.2^{A}$ \\
\hline BL14 & ++ & $10.9 \pm 0.3^{\mathrm{DE}}$ \\
\hline BL20 & + & $10.6 \pm 0.0^{\mathrm{DEF}}$ \\
\hline BL21 & + & $10.3 \pm 0.0^{\mathrm{DEF}}$ \\
\hline BL22 & + & $7.9 \pm 0.5^{\mathrm{FG}}$ \\
\hline BL23 & + & $8.2 \pm 0.1^{\mathrm{FG}}$ \\
\hline BL32 & + & $8.9 \pm 0.4 E F$ \\
\hline BL37 & + & $6.7 \pm 0.0^{\mathrm{F}}$ \\
\hline BL38 & ++ & $11.3 \pm 0.1^{\mathrm{DE}}$ \\
\hline BL48 & ++ & $10.9 \pm 0.5^{\mathrm{DE}}$ \\
\hline BL49 & ++ & $14.0 \pm 0.0^{\mathrm{BCD}}$ \\
\hline BL53 & ++ & $14.1 \pm 0.2^{\mathrm{BCD}}$ \\
\hline BL58 & ++ & $14.1 \pm 0.5^{\mathrm{BCD}}$ \\
\hline BL60 & ++ & $15.4 \pm 0.3^{B C}$ \\
\hline BL61 & ++ & $14.9 \pm 0.0^{\mathrm{BC}}$ \\
\hline BL62 & + & $10.5 \pm 0.2^{\mathrm{DEF}}$ \\
\hline BL63 & ++ & $12.7 \pm 0.5^{\mathrm{CDE}}$ \\
\hline BL64 & ++ & $16.1 \pm 0.0^{B}$ \\
\hline BL65 & ++ & $12.9 \pm 0.0^{C D}$ \\
\hline BL66 & + & $10.8 \pm 0.9^{D E}$ \\
\hline BL70 & ++ & $11.7 \pm 0.5^{\mathrm{DE}}$ \\
\hline BL71 & + & $10.8 \pm 0.2^{\mathrm{DE}}$ \\
\hline BL74 & ++ & $15.5 \pm 0.0^{\mathrm{BC}}$ \\
\hline BL77 & ++ & $11.5 \pm 1.6^{\mathrm{DE}}$ \\
\hline BL84 & ++ & $11.9 \pm 0.4^{\mathrm{DE}}$ \\
\hline BL86 & ++ & $12.4 \pm 0.4 \mathrm{CDE}$ \\
\hline
\end{tabular}

++ : very clear halo; +: clear halo. Results are the mean \pm standard deviation of three experiments. Means followed by different letters are statistically different $(p<0.05)$. 
Table 4 - Lipolytic activity of pre-selected strains in different media studied.

\begin{tabular}{lcccccc}
\hline \multirow{2}{*}{ Strain } & Medium 1 & Medium 2 & Medium 3 & Medium 4 & Medium 5 & Medium 6 \\
\hline $\mathrm{BL} 13$ & $8.8 \pm 0.9^{\mathrm{E}}$ & $8.1 \pm 0.3^{\mathrm{E}}$ & $5.6 \pm 0.2^{\mathrm{EF}}$ & $9.3 \pm 1.0^{\mathrm{DE}}$ & $7.2 \pm 0.7^{\mathrm{EF}}$ & $1.4 \pm 0.1^{\mathrm{G}}$ \\
$\mathrm{BL} 49$ & $6.9 \pm 0.7^{\mathrm{EF}}$ & $4.1 \pm 0.1^{\mathrm{EF}}$ & $2.5 \pm 0.8^{\mathrm{FG}}$ & $2.1 \pm 0.7^{\mathrm{FG}}$ & $3.3 \pm 1.5^{\mathrm{EF}}$ & $1.7 \pm 0.4^{\mathrm{G}}$ \\
$\mathrm{BL} 53$ & $24.9 \pm 1.1^{\mathrm{A}}$ & $19.5 \pm 1.4^{\mathrm{B}}$ & $8.3 \pm 1.6^{\mathrm{E}}$ & $11.1 \pm 1.5^{\mathrm{DE}}$ & $12.8 \pm 0.4^{\mathrm{DE}}$ & $2.8 \pm 0.5^{\mathrm{FG}}$ \\
$\mathrm{BL} 58$ & $8.3 \pm 0.5^{\mathrm{E}}$ & $6.9 \pm 0.1^{\mathrm{EF}}$ & $4.3 \pm 0.7^{\mathrm{EF}}$ & $6.8 \pm 0.4^{\mathrm{EF}}$ & $5.9 \pm 0.8^{\mathrm{EF}}$ & $1.8 \pm 0.1^{\mathrm{G}}$ \\
$\mathrm{BL} 60$ & $8.1 \pm 0.4^{\mathrm{E}}$ & $6.9 \pm 0.3^{\mathrm{EF}}$ & $4.6 \pm 0.8^{\mathrm{EF}}$ & $5.6 \pm 0.3^{\mathrm{EF}}$ & $5.3 \pm 0.5^{\mathrm{EF}}$ & $2.5 \pm 0.8^{\mathrm{FG}}$ \\
$\mathrm{BL} 61$ & $8.6 \pm 0.7^{\mathrm{E}}$ & $10.4 \pm 0.7^{\mathrm{DE}}$ & $3.9 \pm 1.0^{\mathrm{EF}}$ & $5.9 \pm 0.4^{\mathrm{EF}}$ & $6.4 \pm 0.1^{\mathrm{EF}}$ & $1.0 \pm 0.1^{\mathrm{G}}$ \\
$\mathrm{BL} 64$ & $5.4 \pm 0.4^{\mathrm{EF}}$ & $3.9 \pm 0.6^{\mathrm{EF}}$ & $2.1 \pm 0.7^{\mathrm{FG}}$ & $5.0 \pm 0.2^{\mathrm{EF}}$ & $5.5 \pm 0.5^{\mathrm{EF}}$ & $2.2 \pm 0.3^{\mathrm{FG}}$ \\
$\mathrm{BL} 74$ & $24.3 \pm 2.3^{\mathrm{A}}$ & $18.0 \pm 2.3^{\mathrm{BC}}$ & $6.6 \pm 1.6^{\mathrm{EF}}$ & $10.8 \pm 1.0^{\mathrm{DE}}$ & $14.3 \pm 0.4^{\mathrm{C}}$ & $3.3 \pm 0.6^{\mathrm{FG}}$ \\
\hline
\end{tabular}

Means followed by different letters are statistically different $(p<0.05)$.

Table 2 shows the PB experimental design for 12 trials with two levels for each variable and its corresponding lipolytic activity, which varied between 0.5 and 26.7 $U / L$. This variation reflects the importance of optimization to obtain high enzyme production. Although the kinetics of growth has been followed up to 60 hours of cultivation, the largest enzyme activities were observed with 48 hours of cultivation.

The maximum lipolytic activity (26.73 U/L) was obtained in the following conditions: soybean oil and olive oil, $5 \mathrm{~g} / \mathrm{L}$; $\left(\mathrm{NH}_{4}\right)_{2} \mathrm{SO}_{4}, 5 \mathrm{~g} / \mathrm{L}$; glycerol, $30 \mathrm{~g} / \mathrm{L}$; initial $\mathrm{pH}, 5.0 ; 37^{\circ} \mathrm{C}$; inoculum optical density, $5 \%$; absence of Triton X-100 and gum arabic. Lin et al. (2006), working with Antrodia cinnamomea, obtained lipolytic activity, $27 \mathrm{U} / \mathrm{L}$ using glycerol $(50 \mathrm{~g} / \mathrm{L})$ as a carbon source for producing lipase. Bhatnagar et al. (2005), found lipolytic activity maximum of $45 \mathrm{U} / \mathrm{L}$, working with $\mathrm{pH}$ 7.5 and temperature in the range of 35 to $40{ }^{\circ} \mathrm{C}$ in a culture of halobacteria Natronococcus sp.

Among the studied variables, only the inoculum concentration presented no significant effect on confidence level of $95 \%$ in lipase production. Some authors reported that lipases generally are heavily influenced by presence of oils in the culture medium (VOLPATO et al., 2008; BURKERT et al., 2004). In this study, in contrast, the oils (olive and soybean) presented negative effect in the PB experimental design, i.e., when raised from the lower level $(5 \mathrm{~g} / \mathrm{L})$ to the higher level $(20 \mathrm{~g} / \mathrm{L})$ the lipolytic activity decreased.

lqbal and Rehman (2015) utilized different concentrations of oil and when the concentration has exceeded $2 \%$ microbial growth decreased. The microorganisms have the ability to use oil as carbon source, however the high concentration of this 
substrate may be toxic to the cell. According to Magdouli et al. (2017) the depletion of the carbon source (glucose or glycerol) may lead the microorganism to consume the sources of oil, and the increased concentration can lead to decreased activity.

The source of nitrogen is also an important factor for lipase production. In our study, the addition of an inorganic nitrogen source, $\left(\mathrm{NH}_{4}\right)_{2} \mathrm{SO}_{4}$, showed significant effect on lipolytic activity and consequently decreased the proteolytic activity, according to previous experiments. This result is in line to that achieved by Chen et al. (1999), which studied the production of lipase by Acinetobacter radioresistens in a medium containing $1 \mathrm{~g} / \mathrm{L}$ of $\mathrm{NH}_{4} \mathrm{Cl}$ to inhibit proteolytic activity. The emulsifiers, Triton $\mathrm{X}-100\left(\mathrm{X}_{3}\right)$ and gum arabic $\left(\mathrm{X}_{4}\right)$, which was added in order to facilitate and maintain emulsified the oils in the cultivation medium had negative effects on lipolytic activity. This result agrees with obtained by our group when study the lipase production by a Staphylococcus strain (VOLPATO et al., 2008).

Thus, from this result, it was possible to select the variables that most influence in the lipase production by Bacillus circulans BL53, and their levels. The variables that showed significant positive effect, that is the increase in their value leads to an increase in lipase production were: glycerol and $\left(\mathrm{NH}_{4}\right)_{2} \mathrm{SO}_{4}$ concentration, and temperature. The variables that showed significant negative effect, that is the increase in their value leads to an increase in lipase production were: soybean oil, olive oil, Triton X-100, gum Arabic, initial pH. The experimental PB experimental design is exploratory, that is, it only indicates the variables and suggests the values of the levels to be studied to obtain the optimal conditions for cultivation.

\section{CONCLUSIONS}

In this study, we screened and selected Amazon Bacillus strains with lipolytic activity. The results demonstrated that the use of the qualitative solid agar tributyrin technique was an efficient way for the pre-selection of lipase-producing microorganisms, confirmed by the quantitative assay. The Plackett-Burman experimental design was successful used to select the variables that most influence the lipase production by Bacillus circulans BL53. Moreover, it was possible to select a microorganism with high lipolytic activity in a medium containing glycerol as a source of carbon. Furthermore, this work showed that the search and selection of microorganisms with lipolytic activities can facilitate the discovery of new lipases, with 
potential use as by-product surplus, and this result is very important in the economic point of view, with respect to biotechnological processes.

\section{REFERENCES}

ABU, M. L.; NOOH, H. M.; OSLAN, S. N.; SALLEH, A. B. Optimization of physical conditions for the production of thermostable lipase in Pichia guilliermondii strain SO using response surface methodology. BMC Biotechnol, v.17, 2017.

BASSEGODA, A.; FILLAT, A.; PASTOR, F. I. J.; DIAZ, P. Special Rhodococcus sp. CR-53 esterase Est4 contains a GGG(A)X-oxyanion hole conferring activity for the kinetic resolution of tertiary alcohols. Appl Microbiol Biotechnol, v. 19, p. 8559-8568, 2013.

BHATNAGAR, T.; BOUTAIBA, S.; HACENE, H.; CAYOL, J. L.; FARDEAU, M. L.; OLLIVIER, B.; BARRATI, J. C. Lipolytic activity from Halobacteria: Screening and hydrolase production. FEMS Microbiol Lett, v. 248, p. 133-140, 2005.

BURKERT, J. F. M.; MAUGERI, F.; RODRIGUES, M. I. Optimization of extracellular lipase production by Geotrichum sp. using factorial design. Biores Technol, v. 91, p. 77-84, 2004.

CHEN, J.Y.; WEN, C. M.; CHEN, T. L. Effect of oxygen transfer on lipase production by Acinetobacter radioresistens. Biotechnol Bioeng, v. 62, p. 311316, 1999.

GUPTA, N.; MEHRA, G.; GUPTA, R. A glycerol-inducible thermostable lipase from Bacillus sp.: medium optimization by a Plackett-Burman design and by response surface methodology. Canadian J Microbiol, v. 50, p. 361-368, 2004.

IMANDI, S. B.; KARANAM, S. K.; GARAPATI, H. R. Use of Plackett-Burman design for rapid screening of nitrogen and carbon sources for the production of lipase in solid state fermentation by Yarrowia lipolytica from mustard oil cake (Brassica napus). Braz J Microbiol, v. 44, p. 915-921, 2014.

IQBAL, S. A.; REHMAN, A. Characterization of Lipase from Bacillus subtilis I-14 and Its Potential Use in Oil Contaminated Wastewater. Brazilian archives of biology and technology, v. 58, p. 789-797, 2015.

LI, C. Y.; CHEN, S. J; CHENG, C. Y.; CHEN, T. L. Production of Acinetobacter radioresistens lipase with repeated fed-batch culture. Biochem Eng J, v. 25, p. 195-199, 2005.

LIN, E.S.; WANG, C. C.; SUNG, S. C. Cultivating conditions influence lipase production by the edible Basidiomycete Antrodia cinnamomea in submerged culture. Enzyme Microb Technol, v. 39, p. 98-102, 2006. 
MAGDOULI, S.; GUEDRI, T.; TAREK, R.; BRAR, S. K.; BLAIS, J. F. Valorization of raw glycerol and crustacean waste into value added products by Yarrowia lipolytica. Bioresource Technology, v. 243, p. 57-68, 2017.

PLACKETT, R. L.; BURMAN, J. P. The design of optimum multifactorial experiments. Biometrika, v. 33, p. 305-325, 1947.

RAJENDRAN, A.; PALANISAMY, A.; THANGAVELU, V. Evaluation of medium componentes by Plackett-Burman statistical disgn for lipase production by Candida rugosa and kinetic modeling. Chinese Journal of Biothnology, v. 24, p. 436-444, 2008.

RECH, F. R.; VOLPATO, G.; AYUB, M. A. Z. The effects of emulsified polydimethylsiloxane FG-10 on the oxygen transfer coefficient (kLa) and lipase production by Staphylococcus warneri EX17. J Chem Technol Biotechnol, v. 87, p. 990-995, 2012.

SINGH, A. K.; MUKHOPADHYAY, M. Overview of fungal lipase: a review. Applied Biochemistry and Biotechnology, v. 166(2), p. 486-520, 2012.

VASIEE, A.; BEHBAHANI, B.; YAZDI, F. T.; MORADI, S. Optimization of the production conditions of the lipase produced by Bacillus cereus from rice flour through Plackett-Burman Design (PBD) and response surface methodology (RSM). Microb Pathog, v. 101, p. 36-43, 2016.

VOLPATO, G.; RODRIGUES, R. C.; HECK, J. X.; AYUB, M. A. Z. Production of organic solvent tolerant lipase by Staphylococcus caseolyticus EX17 using raw glycerol as substrate. J Chem Technol Biotechnol, v. 83, p. 821-828, 2008.

WINKLER, U.K.; STUCKMANN, M. Glycogen, hyaluronate, and some other polysaccharides greatly enhance the formation of exolipase by Serratia marcescens. J Bacteriol, v. 138, p. 663-670, 1979. 